\title{
Kebergantungan Sifat Fisis dan Mekanis Papan Komposit Berbahan Dasar Sabut Pinang dan Sabut Kelapa pada Variasi Struktur
}

\author{
Irfana Diah Faryuni*, Mentarie Resthu Putri, Asifa Asri, Nurhasanah
}

Program Studi Fisika FMIPA Universitas Tanjungpura, Jl. Prof. Dr. H. Hadari Nawawi, Pontianak

*Email : irfana@physics.untan.ac.id

(Diterima 26 September 2020; Disetujui 25 Mei 2020; Dipublikasikan 16 September 2020)

\begin{abstract}
Abstrak
$\overline{\text { Pada penelitian ini, telah dibuat papan komposit dengan kandungan serat sabut pinang (Areca catechu L.) }}$ dan partikel sabut kelapa (Cocos nucifera L.) yang keduanya berperan sebagai filler. Selain itu, digunakan urea formaldehyde (UF) sebagai matriks, parafin untuk penghambat air, serta $\mathrm{NH}_{4} \mathrm{Cl}$ sebagai katalis. Struktur papan komposit divariasikan sebanyak 2 jenis, yaitu struktur homogen dan sandwich yang akan diuji sifat fisis dan mekanisnya dengan menggunakan standarisasi Japanese Industrial Standars (JIS) A 5908-2003. Struktur homogen terdiri dari 3 sampel, yaitu 100\% serat sabut pinang, 100\% partikel sabut kelapa, dan 50\% serat sabut pinang dicampur 50\% partikel sabut kelapa. Pada struktur sandwich terdapat 2 sampel, yaitu 25\% serat sabut pinang sebagai face dan back serta 50\% partikel sabut kelapa sebagai core dan 25\% partikel sabut kelapa sebagai face dan back serta 50\% serat sabut pinang sebagai core. Hasil penelitian menunjukkan sampel sandwich dengan susunan 25\% serat sabut pinang sebagai face dan back serta 50\% partikel sabut kelapa sebagai core, merupakan sampel yang paling baik yakni memiliki nilai kerapatan $641,36 \pm 18,03 \mathrm{~kg} / \mathrm{m}^{3}$, kadar air 9,88 $\pm 0,49 \%$, daya serap air 118,74 $\pm 25,61 \%$, pengembangan tebal 48,82 $\pm 8,44 \%$, modulus of elasticity 767,90 $\pm 35,41 \mathrm{MPa}$, modulus of rupture 14,45 \pm 4,57 MPa, dan internal bonding 0,17 $\pm 0,04 \mathrm{MPa}$.
\end{abstract}

Kata kunci: papan komposit, sabut pinang, sabut kelapa, variasi struktur

\section{Latar Belakang}

Pepohonan merupakan salah satu sasaran utama dalam pengeksploitasian hasil hutan, sebab dari pohon inilah material bangunan berupa kayu dapat dihasilkan oleh industri yang bergerak dalam bidang pengolahan kayu. Kebutuhan manusia akan kayu untuk konstruksi, bangunan atau furniture terus melaju pesat seiring dengan meningkatnya pertambahan jumlah penduduk, sementara ketersediaan kayu sebagai bahan baku terus menurun [1].

Industri pengolahan kayu di Indonesia diperkirakan memiliki kebutuhan kayu sebesar 70 juta $\mathrm{m}^{3}$ per tahun dengan kenaikan rata-rata sebesar 14,2\% per tahun sedangkan produksi kayu bulat diperkirakan hanya sebesar 25 juta $\mathrm{m}^{3}$ per tahun, dengan demikian terjadi defisit sebesar 45 juta $\mathrm{m}^{3}$ [2]. Hal ini menunjukkan bahwa jumlah bahan baku yang ada tidak dapat memenuhi kebutuhan kayu yang diperlukan oleh industri. Mengingat ketersediaan kayu bulat yang mulai terbatas, maka salah satu upaya yang sudah dikembangkan adalah pembuatan papan komposit.

Berbagai penelitian untuk mencari alternatif pengganti material kayu telah dilakukan, diantaranya adalah pembuatan papan komposit dari serat alam yang belum dimanfaatkan dengan baik. Papan komposit merupakan material yang terbentuk dari dua atau lebih material penyusun. Setiap material penyusun papan komposit memiliki sifat dan karakteristik yang berbedabeda. Hal ini membuat komposit memiliki sifat dan karakteristik yang unik dan lebih unggul dari material penyusunnya. Beberapa keunggulan komposit adalah mudah dibentuk, kuat, ringan, isolator listrik yang baik, anti karat, dan mudah dikombinasikan dengan bahan lain [3].

Penggunaan serat alam pada komposit dapat mencegah peningkatan penggunaan serat sintesis. Penggunaan serat sintetis untuk keperluan industri dapat menimbulkan masalah baru yaitu limbah anorganik. Maka dari itu, penggunaan serat alam sebagai ganti serat sintetis akan mampu mendorong perubahan trend teknologi komposit yang ramah lingkungan [4]. Pengembangan dan penggunaan material komposit berpenguat serat alam dapat menekan harga produksi dikarenakan harga bahan baku yang relatif murah. Selain itu, material komposit dengan serat alam juga ramah lingkungan karena memiliki sifat biodegradable sehingga dapat diurai dengan mudah dan aman serta pemanfaatan yang berkelanjutan [5]. 
Alternatif bahan baku serat alam yang dapat digunakan sebagai filler material komposit diantaranya adalah serat pinang dan sabut kelapa. Sentra tanaman pinang di Indonesia terletak di pulau Sumatera dan pulau Kalimantan. Daerah penyebarannya meliputi Aceh, Riau, Sumatera Utara, dan Kalimantan Barat [6]. Kelapa yang dihasilkan di Indonesia mencapai jutaan ton pertahun. Banyaknya jumlah kelapa yang dihasilkan maka limbah sabut kelapa juga akan semakin meningkat [7]. Serat pinang memiliki kandungan selulosa sebesar 70,2 \%, abu 6,02\%, dan air 10,92\% [8] dan kandungan sabut kelapa terdiri dari 21,07 \% selulosa, 29,23\% lignin, 8,50 $\%$ hemiselulosa, $14,25 \%$ pektin, dan $26 \%$ air [8]. Mengingat ketersediaan serta potensi dari kedua bahan baku ini maka serat pinang dan sabut kelapa cukup potensial dikembangkan sebagai bahan baku pembuatan papan komposit.

Berdasarkan penelitian mengenai komposit dengan bahan serat pinang, komposisi serat mempengaruhi kekuatan tarik dari komposit serat buah pinang, semakin tinggi persentase serat, semakin tinggi pula tegangan yang dihasilkan [9]. Pada sabut kelapa, semakin panjang dan semakin besar fraksi volume serat sabut kelapa dalam komposit, kekuatan tarik, kekuatan impact, dan juga kekuatan lenturnya juga semakin tinggi [10]. Komposit berpenguat serbuk batang kelapa dan serat sabut kelapa menunjukkan kekuatan tarik dan ketangguhan komposit yang lebih baik [11].

Pada penelitian ini, akan dibuat papan komposit dengan bahan sabut pinang dan sabut kelapa. Selama ini, sabut kelapa dimanfaatkan untuk membuat produk keperluan rumah tangga seperti keset, sapu, dan sebagainya [12] sedangkan kulit pinang dimanfaatkan untuk bahan bakar merebus pinang muda [13]. Jika kedua limbah ini dimanfaatkan menjadi bahan baku papan komposit, diharapkan dapat menghasilkan produk komposit baru yang memiliki performa baik. Hasil penelitian ini dapat menjadi salah satu solusi untuk mengurangi jumlah limbah yang menimbulkan masalah bagi lingkungan serta dapat memberikan nilai tambah terhadap sabut kelapa dan sabut pinang dalam proses pembuatan komposit.

Papan komposit yang dibuat pada penelitian ini divariasikan strukturnya menjadi beberapa jenis, yang pertama adalah struktur papan komposit homogen (1 lapisan) yang terdiri atas 3 sample $(100 \%$ serat sabut pinang, $100 \%$ partikel sabut kelapa, dan $50 \%$ serat sabut pinang dicampur 50\% partikel sabut kelapa). Mengingat bahwa penerapan papan komposit kedua bahan baku ini hanya terbatas pada struktur homogen, maka sejalan dengan tren pada dunia komposit juga dibuat papan komposit dengan struktur yang kedua adalah struktur papan komposit sandwich (3 lapisan) yang terdiri atas 2 sampel (25\% serat sabut pinang sebagai face dan back serta 50\% partikel sabut kelapa sebagai core dan 25\% partikel sabut kelapa sebagai face dan back serta $50 \%$ serat sabut pinang sebagai core). Terdapat 5 variasi papan komposit yang akan diuji sifat fisis dan mekanisnya. Pengujian dilakukan sebanyak tiga kali pengulangan kemudian dianalisis menggunakan JIS A 5908-2003.

\section{Metodologi}

\section{A. Alat dan Bahan}

Alat yang digunakan adalah universal testing machine (UTM), oven, hot press, hammermi, ayakan, desikator, timbangan digital, mikrometer sekrup, penggaris, gunting, wadah, gergaji, dan cetakan kayu berukuran $(30 \times 30 \times 1) \mathrm{cm}$. Bahanbahan yang digunakan adalah sabut pinang, sabut kelapa, akuades, larutan $\mathrm{NaOH} 5 \%$, urea formaldehyde (UF), parafin cair yang diproduksi oleh PT. Duta Pertiwi Nusantara, dan katalis $\left(\mathrm{NH}_{4} \mathrm{Cl}\right)$.

\section{B. Persiapan Partikel Sabut Kelapa dan Serat Sabut Pinang}

Limbah sabut pinang dan sabut kelapa masing-masing dibersihkan agar dapat menghilangkan bagian yang tidak diperlukan. Pembersihan limbah kulit pinang dilakukan dengan cara membuang kulit bagian luar dan kulit bagian dalam agar terpisah dengan sabutnya. Pembersihan limbah sabut kelapa dilakukan dengan cara memisahkan sabut dengan bagian ampasnya.

Sabut pinang dan sabut kelapa yang sudah bersih kemudian direndam dengan larutan $\mathrm{NaOH}$ 5\% selama 2 jam, lalu dibilas dengan akuades hingga bersih. Perendaman kedua sabut ini dilakukan secara terpisah. Perendaman ini bertujuan untuk memodifikasi sifat permukaan secara kimiawi sehingga memperbaiki ikatan resin dan fiber karena larutan $\mathrm{NaOH}$ dapat mengurangi hemicelluloses dan lignin pada serat alam [14].

Setelah melewati proses perendaman, masingmasing sabut dijemur selama 3-5 hari setiap kali 


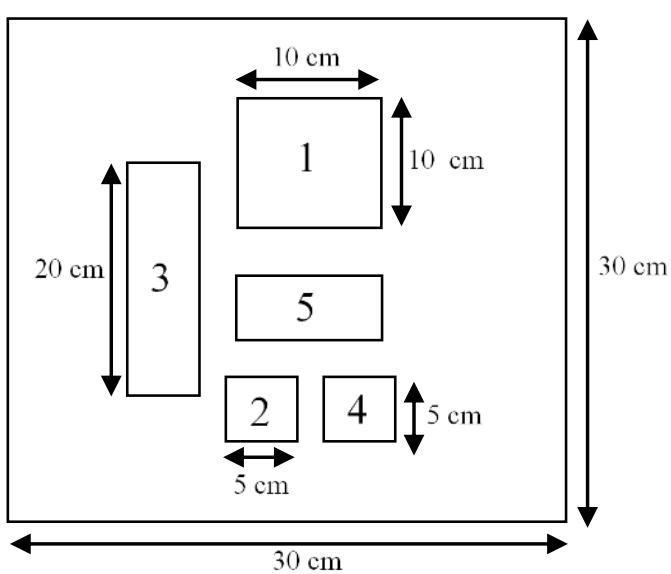

Gambar 1. Skematik pola pemotongan, tampak atas.

rendaman. Sabut kelapa yang sudah dijemur kemudian digiling menggunakan hammermill agar menjadi partikel. Partikel tersebut kemudian diayak dengan saringan lolos 8 mesh tertahan 20 mesh. Pemilihan ukuran 8 mesh tertahan 20 mesh pada partikel sabut kelapa didasarkan pada penelitian papan komposit yang menggunakan partikel kulit durian [15]. Hasil penelitian tersebut menyatakan penggunaan perekat UF dengan konsentrasi $14 \%$ menghasilkan modulus of elasticity (MOE) paling tinggi. Hal ini yang mendasari pemilihan konsentrasi perekat UF sebesar $14 \%$ dengan ukuran partikel lolos saringan 8 mesh tertahan 20 mesh. Sementara itu, untuk sabut pinang dipotong sepanjang $3 \mathrm{~cm}$ lalu diurai-uraikan. Partikel dan serat yang sudah sesuai ukuran kemudian dimasukkan ke dalam oven pada suhu $60^{\circ} \mathrm{C}$ selama 24 jam untuk mencapai kadar air 4-6\%. Pada jarak temperatur sekitar $100-200{ }^{\circ} \mathrm{C}$, akan terjadi pengurangan massa sebesar kurang lebih 12\% [16]. Penggunaan suhu yang lebih tinggi pada waktu 24 jam akan sangat mengurangi bobot bahan yang akan digunakan serta menyebabkan bahan baku akan mengalami kerusakan seperti terbakar dan menjadi abu. Untuk membuat 1 papan komposit ukuran 30x30x1 cm dengan target kerapatan 0,7 $\mathrm{g} / \mathrm{cm}^{3}$, dibutuhkan massa sebanyak 630 g. Jika diawal pemrosesan massa yang hilang selama pengovenan terlalu banyak, akan terlalu banyak limbah yang harus digunakan hanya untuk membuat 1 papan saja. Selain itu, standar uji untuk kadar air pada JIS A 5908-2003 mensyaratkan agar papan komposit memiliki kadar air 5-13\%, jika diawal pemrosesan sabut sudah kehilangan banyak kadar air, maka saat proses pengempaan papan komposit, kadar air pada sampel beresiko untuk melewati batas yang disyaratkan pada JIS A 5908-2003.

Secara umum, serat pinang memiliki kandungan selulosa sebesar 70,2 \%, abu 6,02\%, dan air 10,92\% [8] dan kandungan sabut kelapa terdiri dari 21,07 \% selulosa, 29,23\% lignin, 8,50 $\%$ hemiselulosa, $14,25 \%$ pektin, dan $26 \%$ air [17]. Maka dari itu, walaupun terdapat berbagai jenis pohon pinang maupun kelapa, sebaran lokasi tumbuhnya kedua pohon serta variasi masa panen kualitas kedua bahan baku tersebut akan menghasilkan produk dengan kualitas yang sama jika dilakukan perulangan produksi.

\section{C. Pembuatan Papan Komposit}

Langkah awal dalam pembuatan papan komposit adalah menentukan fraksi massa serat sabut pinang, partikel sabut kelapa, urea formaldehyde, parafin, dan katalis. Langkah selanjutnya adalah melakukan pencampuran partikel dan serat dengan urea formaldehyde, parafin dan katalis.

Setelah itu, adonan serat dan partikel dimasukkan ke dalam cetakan berukuran $(30 \times 30 \times 1) \mathrm{cm}$ sesuai dengan penempatan lapisan yang telah dirancang dalam penelitian ini dengan target kerapatan sebesar $0,7 \mathrm{~g} / \mathrm{cm}^{3}$. Kemudian cetakan ditutup dan ditekan secara manual hingga penutup cetakan menekan bahan secara merata. Bahan yang sudah dicetak kemudian dimasukkan ke dalam hot press dengan tekanan 30 Pa pada suhu $150^{\circ} \mathrm{C}$ selama 8 menit $[18,19]$. Suhu pengempaan yang rendah perlu diimbangi dengan waktu yang lama. Suhu yang terlalu rendah ataupun terlalu tinggi akan mengurangi keteguhan rekatnya [20]. Papan komposit yang telah dicetak kemudian didiamkan selama 8 hari sebelum pengujian. Pada penelitian ini terdapat 5 sampel papan komposit yang dibuat masingmasing sebanyak 3 kali pengulangan untuk kemudian diuji sifat fisis dan mekanisnya. Tujuan pengulangan ini adalah untuk melihat apakah hasil nilai yang dihasilkan bersifat reproducible.

\section{D. Pemotongan Sampel Uji}

Papan partikel yang telah dilakukan pengkondisian kemudian dipotong menggunakan mesin gergaji sesuai pola yang telah dibuat dengan acuan standar JIS A 5908-2003. Gambar 1 menunjukkan skematis pola pemotongan sampel dilihat dari atas. Keterangan pada gambar ini, 1 adalah sampel uji untuk kerapatan dan kadar air berukuran $(10 \times 10 \times 1) \mathrm{cm}, 2$ adalah sampel uji 
untuk daya serap air dan pengembangan tebal berukuran $(5 \times 5 \times 1) \mathrm{cm}, 3$ adalah sampel uji untuk MOE dan MOR berukuran $(5 \times 20 \times 1) \mathrm{cm}$, 4 sampel uji untuk kekuatan rekat internal berukuran $(5 \times 5 \times 1) \mathrm{cm}, 5$ sampel uji cadangan.

\section{E. Pengujian Papan Komposit}

\section{a. Kerapatan Papan}

Massa kering sampel diukur di udara dan dimensi sampel, meliputi panjang, lebar, dan tebal juga diukur untuk mengetahui volume sampel tersebut. Kerapatan papan dihitung menggunakan persamaan [21]:

$$
\rho=\frac{m}{v},
$$

dengan $\rho$ adalah erapatan papan $\left(\mathrm{kg} / \mathrm{m}^{3}\right), m$ adalah massa sampel uji (kg), $v$ adalahvolume sampel uji $\left(\mathrm{m}^{3}\right)$

\section{b. Kadar Air}

Massa kering sampel udara di udara diukur, kemudian sampel dioven pada suhu $102 \pm 3^{\circ} \mathrm{C}$ selama 24 jam. Setelah itu, sampel dimasukan ke dalam desikator selama 10 menit. Nilai kadar air dihitung dengan [21]:

$$
\text { Kadar air }=\frac{B A-B K O}{B K O} \times 100 \% .
$$

Pada persamaan ini, BA adalah massa awal sampel uji $(\mathrm{kg})$ dan BKO adalah massa sampel uji setelah dioven $(\mathrm{kg})$.

\section{c. Daya Serap Air}

Massa sampel kering di udara (B0) ditimbang. Kemudian, sampel direndam dalam air yang relatif bersuhu dingin selama 24 jam. Resin komposit akan menyerap air lebih tinggi jika direndam pada suhu yang lebih tinggi [22]. Peningkatan suhu akan meningkatkan penyerapan air dan kelarutan resin komposit [23]. Kemudian sampel diangkat dan ditiriskan sampai tidak ada lagi air yang menetes, selanjutnya ditimbang kembali beratnya (B1). Nilai daya serap air dihitung menggunakan persamaan [21]

$$
\text { Daya serap air }=\frac{B 1-B 0}{B 0} \times 100 \%,
$$

dengan B0 adalah massa awal sampel uji (kg) dan B1 adalah massa sampel uji setelah perendaman (kg)

\section{d. Pengembangan Tebal}

Sampel direndam dalam air selama 24 jam. Kemudian, pengembangan tebal papan komposit yang menyerap air dihitung dengan [21]:
Pengembangan tebal $=\frac{T 1-T 0}{T 0} \times 100 \%$,

dengan T0 adalah ketebalan awal sampel uji (m) dan $\mathrm{T} 1$ adalah ketebalan setelah perendaman (m).

\section{e. Modulus of Elasticity (MOE)}

Pengujian dilakukan menggunakan alat uji mekanis yaitu universal testing machine (UTM). Sampel dibentangkan dengan jarak sangga $15 \mathrm{~cm}$. Selanjutnya, pembebanan dilakukan di tengahtengah jarak sangga. Nilai MOE dihitung dengan [21]:

$$
\mathrm{MOE}=\frac{\Delta \mathrm{PL}^{3}}{4 \Delta \mathrm{ybh}^{3}},
$$

dengan, $\Delta \mathrm{P}$ adalah perubahan beban yang dicatat alat $(\mathrm{N}), \mathrm{L}$ adalah jarak sangga $(\mathrm{m}), \Delta \mathrm{y}$ adalah perubahan defleksi setiap perubahan beban yang dicatat alat (m), b adalah lebar sampel (m), dan $\mathrm{h}$ adalah tebal sampel (m).

\section{f. Modulus of Rupture (MOR)}

Pengujian modulus patah dilakukan menggunakan sampel dan alat uji yang sama dengan pengujian modulus elastisitas. Nilai MOR dapat dihitung menggunakan persamaan [21]:

$$
\text { MOR }=\frac{3 P L}{2 b^{2}},
$$

dengan $\mathrm{P}$ adalah pembebanan yang dicatat alat $(\mathrm{N})$, L adalah jarak sangga (m), b adalah lebar sampel (m), h adalah tebal sampel (m)

\section{g. Kekuatan Rekat Internal (Internal Bonding)}

Sampel direkatkan pada dua blok besi dengan perekat eроху dan dibiarkan selama 15 menit sampai mengeras. Kedua blok besi ditarik tegak lurus permukaan sampel sampai beban maksimum (sampel rusak). Nilai keteguhan rekat internal, IB, dihitung sebagai berikut [21]:

$$
\mathrm{IB}=\frac{P_{\max }}{A},
$$

dengan $P_{\max }$ adalah beban maksimum $(\mathrm{N}) \operatorname{dan} A$ adalah luas permukaan sampel $\left(\mathrm{m}^{2}\right)$.

\section{Hasil dan Pembahasan}

\section{A. Kerapatan Papan Komposit}

Kerapatan merupakan perbandingan antara berat sampel uji dengan volumenya. Nilai kerapatan ini merupakan nilai kerapatan rerata dari 3 kali pengulangan pada masing-masing sampel. Gambar 2 menunjukkan nilai kerapatan papan komposit yang telah dihitung menggunakan 


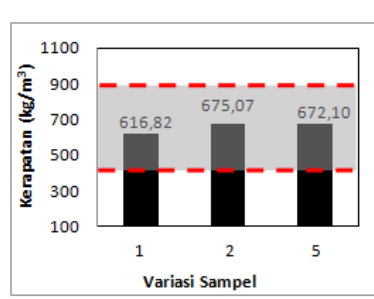

(a)

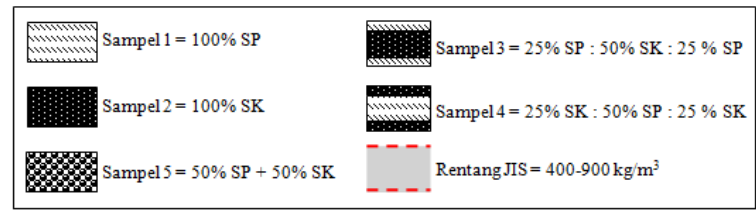

Gambar 2. Grafik nilai kerapatan papan komposit untuk struktur (a) homogen dan (b) sandwich

Persamaan (1) adalah antara 616,82 + 62,00 s.d. $675,07+24,94 \mathrm{~kg} / \mathrm{m} 3$. Kerapatan tertinggi didapat pada sampel 2 berbahan $100 \%$ partikel sabut kelapa dan nilai kerapatan terendah pada sampel 1 berbahan $100 \%$ serat sabut pinang. Standarisasi JIS A 5908-2003 menyatakan kerapatan papan komposit akan memenuhi standar jika ada di rentang nilai 400 s.d. $900 \mathrm{~kg} / \mathrm{m} 3$. Berdasarkan Gambar 2, dapat dilihat bahwa semua variasi papan komposit memenuhi standarisasi JIS A 5908-2003 untuk kategori kerapatan.

Besar kecilnya kerapatan yang dihasilkan memiliki keterkaitan dengan distribusi partikel dalam papan [24]. Hal ini disebabkan oleh ukuran partikel yang lebih kecil dapat menjalin ikatan rekat antar partikel yang lebih baik dibandingkan dengan partikel yang lebih kasar sewaktu proses pengempaan panas berlangsung. Pada penelitian ini, digunakan partikel sabut kelapa yang ukurannya lebih kecil dari serat sabut pinang.

Faktor lain yang menjelaskan tentang nilai kerapatan adalah pengaruh bahan baku yang digunakan yakni semakin rendah kerapatan bahan baku yang digunakan, semakin tinggi kerapatan papan yang dihasilkan [25]. Sabut kelapa memiliki densitas $1,15 \mathrm{~kg} / \mathrm{m}^{3}$ [26] sedangkan sabut pinang memiliki densitas sebesar $0,159 \mathrm{gr} / \mathrm{cm}^{3}$ atau setara dengan $159 \mathrm{~kg} / \mathrm{m}^{3}$ [27].

Nilai kerapatan papan komposit pada struktur sandwich untuk kedua sampel tidak berubah signifikan (cenderung sama). Hal ini menunjukkan tidak adanya pengaruh antara posisi filler yang berjenis partikel maupun serat jika digunakan sebagai core maupun face/back. Sedangkan pada sampel 5 (papan homogen dengan campuran filler $50 \%$ serat sabut pinang dan $50 \%$ partikel sabut kelapa), nilai kerapatannya berada di tengahtengah antara sampel 1 dan sampel 2. Hal ini

dikarenakan massa jenisnya merupakan massa jenis rata-rata dari kedua bahan sampel tersebut.

\section{B. Kadar Air Papan Komposit}

Nilai kadar air yang disajikan pada Gambar 3 merupakan nilai rerata dari 3 kali pengulangan pada masing-masing sampel. Setelah dihitung menggunakan persamaan (2), grafik nilai kadar air papan komposit pada gambar tersebut berkisar antara $9,79 \pm 0,36$ s.d. $11,62 \pm 1,72 \%$. Kadar air tertinggi didapat pada sampel 1 berbahan $100 \%$ serat sabut pinang dan nilai kadar air terendah pada sampel 2 berbahan $100 \%$ partikel sabut kelapa. Standarisasi JIS A 5908-2003 menyatakan kadar air papan komposit akan memenuhi standar jika ada di rentang nilai 5-13\%. Gambar 3 menunjukkan bahwa kadar air semua variasi papan komposit memenuhi standarisasi JIS A 5908-2003.

Kadar air papan komposit dipengaruhi oleh kerapatannya [26]. Papan dengan kerapatan tinggi memiliki ikatan antara partikel dengan molekul perekat dapat terbentuk dengan kuat. Hal tersebut menyebabkan molekul air sulit mengisi rongga yang terdapat dalam papan komposit karena telah terisi dengan molekul perekat.

Kadar air papan komposit juga dipengaruhi oleh keadaan pengkondisian karena pada saat itu papan komposit akan menyerap air dari lingkungannya. Kadar air papan komposit sangat tergantung pada kondisi udara disekitarnya, karena bahan baku papan komposit adalah bahanbahan yang mengandung lignoselulosa yang bersifat higroskopis [29]. Sabut pinang mengandung $70,2 \%$ selulosa [8], sedangkan sabut kelapa memiliki kandungan selulosa sebanyak $21,07 \%$ [29]. Hal ini menyebabkan sifat higroskopis sampel dengan filler serat sabut

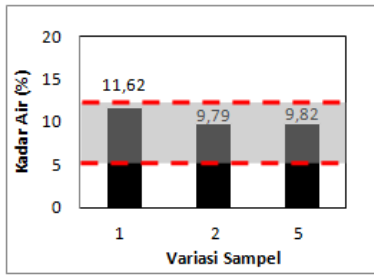

(a)

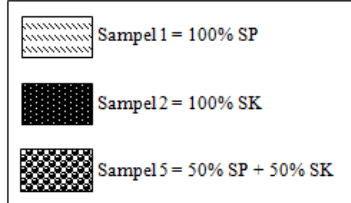

Gambar 3. Grafik nilai kadar air papan komposit untuk struktur (a) homogen dan (b) sandwich. 
pinang lebih tinggi dibandingkan sampel dengan filler partikel sabut kelapa.

Nilai kadar air papan komposit pada struktur sandwich untuk kedua sampel tidak berubah signifikan (cenderung konstan). Hal ini menunjukkan tidak ada pengaruh antara posisi filler yang berjenis partikel ataupun serat jika digunakan sebagai core maupun face/back. Faktor penyebabnya adalah nilai kerapatan yang tidak berbeda antara kedua sampel. Sedangkan pada papan komposit dengan campuran filler 50\% serat sabut pinang dan 50\% partikel sabut kelapa (sampel 5) nilainya berada di tengah-tengah antara sampel 1 dan sampel 2 hal ini dikarenakan kadar airnya merupakan kadar air rata-rata dari kedua bahan tersebut.

\section{C. Daya Serap Air Papan Komposit}

Daya serap air merupakan kemampuan papan komposit dalam menyerap air. Nilai daya serap air ini merupakan nilai rerata dari 3 kali pengulangan pada masing-masing sampel yang dihitung dengan persamaan (3).

Gambar 4 menunjukkan nilai daya serap air papan komposit adalah antara $87,08+2,17$ s.d. $182,87+48,21 \%$. Daya serap air tertinggi didapat pada sampel 1 berbahan 100\% serat sabut pinang dan nilai daya serap air terendah pada sampel 4 berbahan 25\% partikel sabut kelapa sebagai face dan back serta 50\% serat sabut pinang sebagai core. Standar JIS A 5908-2003 tidak mensyaratkan nilai untuk daya serap air, namun pengujian ini tetap dilakukan guna mengetahui ketahanan papan komposit yang dihasilkan terhadap air.

Sampel 3 memiliki nilai daya serap air yang lebih besar dari sampel 4. Hal ini bersesuaian dengan hasil pada struktur homogen, bahwa filler berjenis serat memiliki nilai daya serap air yang

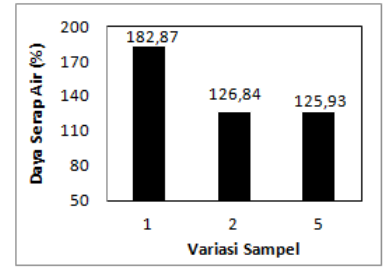

(a)

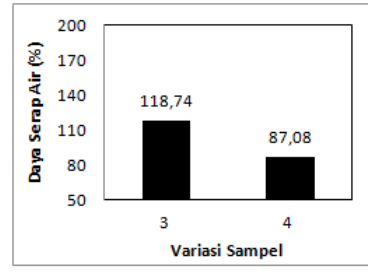

(b)

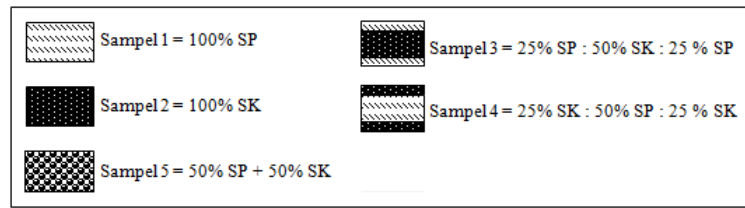

Gambar 4. Grafik nilai daya serap air papan komposit untuk struktur (a) Homogen dan (b) sandwich. jauh lebih tinggi dibandingkan filler berjenis partikel. Pada struktur sampel 3, serat sabut pinang diposisikan sebagai face dan back sehingga pada saat perendaman, partikel pada core tidak dapat berperan sebagai penekan laju daya serap air yang terserap pada serat. Pada struktur sampel 4, saat air masuk ke dalam serat yang diposisikan sebagai core dan mengalami pengembangan, partikel pada face dan back akan menahan laju pengembangan tebal sehingga nilai daya serap air menjadi lebih kecil dibandingkan sampel 3 . Sedangkan pada papan komposit dengan campuran filler 50\% serat sabut pinang dan 50\% partikel sabut kelapa (sampel 5) nilainya berada di tengah-tengah antara sampel 1 dan sampel 2 hal ini disebabkan oleh daya serap airnya merupakan rata-rata dari kedua bahan tersebut.

Penyerapan air oleh papan partikel dipengaruhi oleh beberapa faktor antara lain volume rongga atau ruang kosong yang dapat menampung air diantara partikel, luas permukaan partikel yang tidak dapat ditutupi perekat, dan dalamnya penetrasi perekat dalam partikel [30]. Tingginya nilai daya serap air diseabakan oleh sebaran perekat yang tidak merata sehingga sifat perekat akan mudah terhidrolisis oleh air yang kemudian mengakibatkan daya ikat perekat mudah lepas ketika papan partikel direndam [31].

\section{D. Pengembangan Tebal Papan Komposit}

Nilai pengembangan tebal ini merupakan nilai rerata dari 3 kali pengulangan pada setiap sampel. Persamaan (4) digunakan untuk mengitung nilai tersebut.

Gambar 5 menunjukkan nilai pengembangan tebal papan komposit adalah antara 28,92 + 3,83 s.d. 59,65 + 17,22 \%. Pengembangan tebal tertinggi didapat pada sampel 1 berbahan $100 \%$ serat sabut

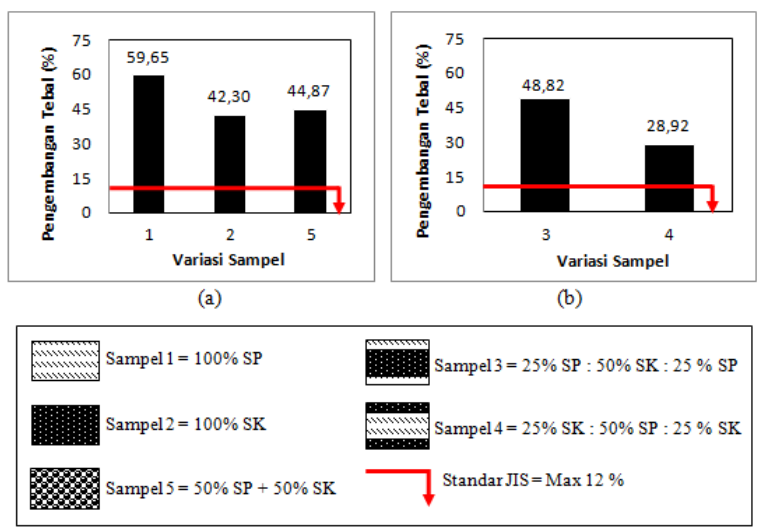

Gambar 5. Grafik nilai pengembangan tebal papan komposit untuk struktur (a) homogen dan (b) Sandwich. 
pinang dan pengembangan tebal terendah pada sampel 4 berbahan $25 \%$ partikel sabut kelapa sebagai face dan back serta $50 \%$ serat sabut pinang sebagai core. Standarisasi JIS A 5908-2003 menyatakan pengembangan tebal papan komposit akan memenuhi standar apabila nilainya maksimal 12\%. Berdasarkan Gambar 5, dapat dilihat bahwa semua variasi papan komposit tidak memenuhi standarisasi JIS A 5908-2003 untuk kategori pengembangan tebal. Pembahasan mengenai pengembangan tebal sama halnya dengan kadar air dan daya serap air karena nilai yang ditunjukkan pada grafik untuk ketiga indikator tersebut menghasilkan trend kurva linier.

Pada umumnya, semakin tinggi sifat daya serap air, semakin tinggi pula sifat pengembangan tebal, begitu juga sebaliknya [32]. Pengembangan tebal dapat disebakan oleh absorbsi air, karena semakin banyak air yang diabsorbsi dan memasuki struktur partikel maka semakin banyak pula perubahan dimensi yang dihasilkan [33].

\section{E. MOE Papan Komposit}

Nilai MOE pada Gambar 6 merupakan nilai kerapatan rerata dari 3 kali pengulangan pada masing-masing sampel. Nilai MOE didapatkan dari hasil perhitungan menggunakan persamaan (5).

Gambar 6 menunjukkan nilai MOE papan komposit adalah antara 391,85 + 89,37 s.d. 767,90 $+35,41 \mathrm{MPa}$. MOE tertinggi didapat pada sampel 3 berbahan $25 \%$ serat sabut pinang sebagai face dan back serta $50 \%$ partikel sabut kelapa sebagai core dan MOE terendah pada sampel 2 berbahan 100\% partikel sabut kelapa. Standarisasi JIS A 5908-2003 menyatakan MOE papan komposit akan memenuhi standar apabila nilainya minimal 199,92×107 $\mathrm{N} / \mathrm{m} 2$ atau setara 1.999,2 MPa. Berdasarkan Gambar 6 dapat dilihat bahwa semua variasi

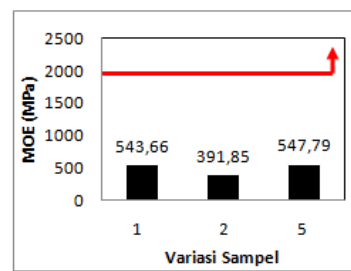

(a)

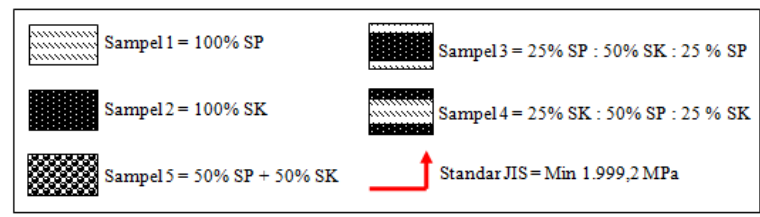

Gambar 6. Grafik nilai MOE papan komposit untuk struktur (a) homogen dan (b) sandwich. papan komposit tidak memenuhi standarisasi JIS A 5908-2003 untuk kategori MOE.

Papan komposit struktur homogen pada sampel 1 dengan filler serat sabut pinang memiliki nilai MOE yang cukup tinggi jika dibandingkan dengan sampel 2 yang memiliki filler berupa partikel sabut kelapa. Salah satu penyebab hal tersebut adalah faktor ukuran partikel. Semakin besar ukuran partikel maka nilai MOE yang dihasilkan juga semakin tinggi [34]. Apabila ditinjau dari bentuknya, serat juga akan memiliki nilai MOE yang lebih besar dibandingkan dengan jenis partikel. Filler yang berbentuk serat akan mampu mendistribusikan tekanan yang dirasakan ke sepanjang seratnya, jadi akan lebih sulit patah dibandingkan filler yang berupa partikel. Serat panjang dapat mengalirkan beban maupun tegangan dari titik tegangan ke arah serat yang lain [35].

Papan komposit struktur sandwich pada sampel 3 memiliki nilai MOE yang lebih besar dibandingkan sampel 4. Hal ini sesuai dengan hasil pada struktur homogen, bahwa filler berjenis serat memiliki nilai MOE yang jauh lebih tinggi dibandingkan filler berjenis partikel. Pada struktur sampel 4, saat papan terus menerus diberikan tekanan dari atas terlihat bahwa pada bagian back mengalami patahan terlebih dahulu. Hal ini dikarenakan filler pada back berupa partikel, dimana nilai MOE-nya jauh lebih kecil dibandingkan filler serat sehingga beban yang diterima akan terfokus di satu titik saja. Sedangkan pada sampel 3 (bagian face dan back berupa serat) saat papan diberikan tekanan terus menerus, maka serat mampu menopang gaya dan merambatkan energinya sehingga nilai MOE-nya lebih tinggi daripada sampel 4.

Sampel 5 yang merupakan papan komposit struktur homogen dengan campuran filler 50\% serat sabut pinang dan $50 \%$ partikel sabut kelapa nilainya akan berada di tengah-tengah atau tidak jauh dari nilai MOE pada sampel 1 dan sampel 2 . Hal ini dikarenakan material yang digunakan merupakan gabungan dari kedua bahan pada sampel tersebut.

\section{F. MOR Papan Komposit}

Nilai MOR pada Gambar 7 merupakan nilai kerapatan rerata dari 3 kali pengulangan pada setiap sampel papan komposit. Persamaan (6) digunakan untuk mengitung nilai tersebut. 


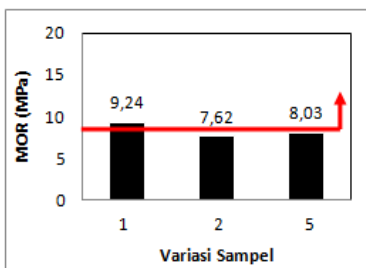

(a)

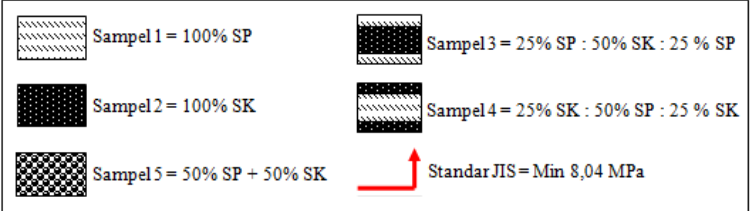

Gambar 7. Grafik nilai MOR papan komposit untuk struktur (a) homogen dan (b) sandwich.

Nilai MOR yang disajikan merupakan nilai MOR rerata dari 3 kali pengulangan pada masingmasing sampel. Gambar 7 menunjukkan nilai MOR papan komposit adalah antara 7,62 $\pm 2,30$ s.d. $14,45 \pm 4,57 \mathrm{MPa}$. MOR tertinggi didapat pada sampel 3 berbahan $25 \%$ serat sabut pinang sebagai face dan back serat 50\% partikel sabut kelapa sebagai core dan MOR terendah pada sampel 2 berbahan $100 \%$ partikel sabut kelapa. Standarisasi JIS A 5908-2003 menyatakan MOR papan komposit akan memenuhi standar apabila nilainya minimal $804 \times 10^{4} \mathrm{~N} / \mathrm{m}^{2}$ atau setara 8,04 MPa. Berdasarkan Gambar 7 dapat dilihat bahwa variasi papan komposit yang memenuhi standarisasi JIS A 5908-2003 untuk kategori MOR adalah sampel 1,3 dan 4 .

Pembahasan mengenai MOR sama halnya dengan MOE karena nilai yang ditunjukkan pada grafik untuk kedua indikator tersebut menghasilkan trend kurva linier. Secara keseluruhan sampel dengan penempatan serat sabut pinang dalam bentuk layer (sampel 1, 3, dan 4) memiliki nilai MOR yang lebih tinggi dari pada sampel dengan serat sabut pinang yang tersebar secara acak (sampel 5). Sampel 2 yang sama sekali tidak terdapat serat sabut pinang menjadi sampel dengan MOR terendah. Hasil tersebut menunjukkan bahwa serat sabut pinang yang memiliki ukuran lebih besar dari partikel sabut kelapa dapat berperan sebagai penguat pada papan komposit yang dihasilkan.

\section{G. IB Papan Komposit}

Nilai IB yang disajikan pada Gambar 8 merupakan nilai kerapatan rerata dari 3 kali pengulangan pada masing-masing sampel. Nilai ini didapatkan dari hasil pengolahan data menggunakan persamaan (7).

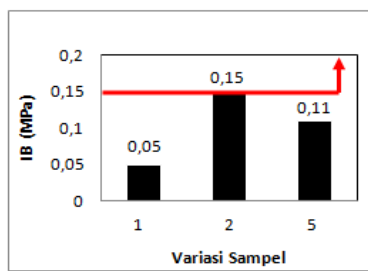

(a)

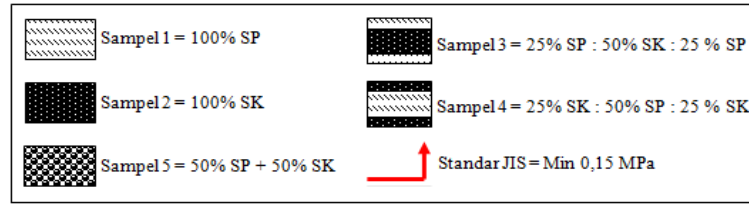

Gambar 8. Grafik nilai IB papan komposit untuk struktur (a) homogen dan (b) sandwich.

Grafik di Gambar 8 menunjukkan nilai IB papan komposit sebesar antara $0,05+0,03$ s.d. $0,17+0,04 \mathrm{MPa}$. IB tertinggi didapat pada sampel 3 berbahan $25 \%$ serat sabut pinang sebagai face dan back serta $50 \%$ partikel sabut kelapa sebagai core dan IB terendah pada sampel 1 berbahan $100 \%$ serat sabut pinang. Standarisasi JIS A 59082003 menyatakan IB papan komposit akan memenuhi standar apabila nilainya minimal $15 \times 104 \mathrm{~N} / \mathrm{m}^{2}$ atau setara 0,15 MPa. Berdasarkan Gambar 4.8 dapat dilihat bahwa variasi papan komposit yang memenuhi standarisasi JIS A 59082003 untuk kategori IB adalah sampel 2, 3 dan 4.

Papan komposit struktur homogen dengan filler partikel sabut kelapa (sampel 2) memiliki nilai IB yang cukup tinggi jika dibandingkan dengan papan komposit dengan filler serat sabut pinang (sampel 1). Salah satu faktor yang mempengaruhinya adalah besarnya kerapatan. Sampel 2 memiliki nilai kerapatan yang jauh lebih tinggi dari sampel 1. Hal ini menyebabkan saat dilakukan penarikan pada bagian atas dan bawah, sampel dengan kerapatan tinggi akan cenderung memiliki nilai IB yang besar begitu pula sebaliknya, saat kerapatan rendah maka nilai IB akan cenderung kecil.

Karakteristik filler juga dapat mempengaruhi besar kecilnya nilai IB. Filler yang berupa serat akan cenderung memiliki ikatan yang lemah antar material penyusun yang lainnya dibandingkan filler partikel. Hal ini karena luas permukaan serat lebih kecil dibandingkan filler yang berupa partikel sehingga nilai IB partikel menjadi lebih tinggi dibandingkan nilai IB pada serat.

Setelah dilakukan pengujian internal bonding, komposit struktur sandwich menunjukkan bagian yang mengalami kerusakan atau daerah yang 
mengalami pemisahan adalah bagian face/back dan core berupa serat. Hal ini juga sesuai dengan hasil pada struktur homogen, bahwa filler berjenis serat memiliki nilai IB yang jauh lebih rendah dibandingkan filler berjenis partikel.

Sampel 5 yang merupakan papan komposit struktur homogen dengan campuran filler 50\% serat sabut pinang dan 50\% partikel sabut kelapa, nilainya berada di tengah-tengah antara sampel 1 dan sampel 2 hal ini dikarenakan nilai IB sampel tersebut merupakan rata-rata dari kedua bahan pada sampel 1 dan sampel 2. Sampel 5 memiliki nilai IB yang tidak lebih rendah dari sampel 1 namun juga tidak lebih tinggi dari sampel 2. Nilai nilai parameter sifat fisis dan sifat mekanis yang telah diperoleh pada penelitian ini yaitu kerapatan, kadar air, daya serap air, pengembangan tebal, MOE, MOR, dan internal bonding, merupakan penyempurnaan dari beberapa penelitian sebelumnya $[9,11]$ yang hanya berpusat pada kekuatan tariknya dan kekuatan mekaniknya saja.

\section{Kesimpulan}

Pada penelitian ini, telah dibuat papan komposit dengan kandungan serat sabut pinang (Areca catechu L.) dan partikel sabut kelapa (Cocos nucifera L.) yang keduanya berperan sebagai filler. Selain itu, digunakan urea formaldehyde (UF) sebagai matriks, parafin untuk penghambat air, serta $\mathrm{NH}_{4} \mathrm{Cl}$ sebagai katalis untuk mempercepat reaksi pembentukan papan komposit saat proses pengempaan. Struktur papan komposit divariasikan sebanyak 2 jenis, yaitu struktur homogen dan sandwich yang akan diuji sifat fisis dan mekanisnya dengan menggunakan standarisasi Japanese Industrial Standars (JIS) A 5908-2003. Struktur homogen terdiri dari 3 sampel, yaitu $100 \%$ serat sabut pinang, $100 \%$ partikel sabut kelapa, dan $50 \%$ serat sabut pinang dicampur $50 \%$ partikel sabut kelapa. Pada struktur sandwich terdapat 2 sampel, yaitu $25 \%$ serat sabut pinang sebagai face dan back serta $50 \%$ partikel sabut kelapa sebagai core dan $25 \%$ partikel sabut kelapa sebagai face dan back serta $50 \%$ serat sabut pinang sebagai core.

Variasi struktur yang paling baik pada penelitian ini adalah papan komposit berstruktur sandwich jika dibandingkan struktur homogen. Pada struktur sandwich, pemilihan material filler sebagai face dan back serta core berpengaruh signifikan pada sifat fisis dan mekanis papan komposit yang dihasilkan. Papan komposit dengan struktur sandwich yang memiliki susunan 25\% serat sabut pinang sebagai face dan back serta $50 \%$ partikel sabut kelapa sebagai core memiliki sifat fisis dan sifat mekanis yang paling baik dibandingkan dengan struktur homogen maupun sampel yang lainnya yakni memiliki nilai kerapatan sebesar $641,36 \pm 18,03 \mathrm{~kg} / \mathrm{m}^{3}$, kadar air sebesar 9,88 $\pm 0,49 \%$, daya serap air sebesar $118,74 \pm 25,61 \%$, pengembangan tebal sebesar $48,82 \pm 8,44 \%$, MOE sebesar 767,90 $\pm 35,41 \mathrm{MPa}$, MOR sebesar 14,45 \pm 4,57 MPa, dan IB sebesar $0,17 \pm 0,04 \mathrm{MPa}$

\section{Daftar Pustaka}

[1] Lubis, M., Jamilah, Risnasari, I., Nuryawan, A. dan Febrianto, F., Kualitas Papan Komposit dari Limbah Batang Kelapa Sawit (Elaeis guineensis Jacq) dan Polyethylene (Pe) Daur Ulang, IPB, Bogor, 2009.

[2] Priyono, K.D., Geomorfologi Pantai dan Pengelolaan Wilayah Pesisir, Fakultas Geografi, UMS, Surakarta, 1996.

[3] Syamani, A.F., Prasetyo, K.W., Budiman, I, Subyakto dan Subiyanto, B., Sifat Fisis Mekanis Papan Partikel dari Serat Sisal atau Serat Abaka Setelah Perlakuan Uap, J.Tropical Wood Science and Technologi, 6(2), pp. 5662, 2008.

[4] Sisworo, S., Pengaruh Penggunaan Serat Kulit Rotan Sebagai Penguat pada Komposit Polimer dengan Matriks Polyester Yucalac 157 terhadap Kekuatan Tarik dan Tekuk, Jurnal Teknik, 30(3), pp. 191-196, 2009.

[5] Biswas, S., Srikanth, G. and Nangia, N., Develpoment of Natural Fibre Composites in India, 2001 Convention and Trade Show, Florida USA: Composites Fabricators Association, 2001.

[6] Maskromo, I. dan Miftahorrachman, Keragaman Genetik Plasma Nutfah Pinang (Areca catechu L.), Jurnal LTTRI, 13(4), 199124, 2007.

[7] Irwan, Y. dan Syam, I.I., Pengujian Transmission Loss pada Papan Serat Sabut Kelapa dan Aluminium Hollow Bar dengan Matriks Gypsum, Rekayasa dan Aplikasi Teknik Mesin di Industri Teknik, ITENAS, Bandung, 2013.

[8] Ruslinda, R., Kandungan Serat Buah Pinang, ITB, Bandung, 2008.

[9] Fahmi, H., Hadi, S. dan Kapur F.M., Analisis Kekuatan Komposit Resin diperkuat Serat Pinang, Jurnal Teknik Mesin Institut Teknoligi Padang, 6(2), 86-91, 2016.

[10] Astika, I.M., Lokantara, I.P. dan Karohika I.M.G, Sifat Mekanis Komposit Polyester 
dengan Penguat Serat Sabut Kelapa, Jurnal Energi Manufaktur, 6(2), 95-202, 2013.

[11] Lumintang, R.C.A., Soenoko R. dan Wahyudi S., Komposit Hibrit Polyester Berpenguat Serbuk Batang dan Serat Sabut Kelapa, Jurnal Rekayasa Mesin, 2(2), 145-153, 2011.

[12] Sudarsono, Rusianto, T. dan Suryadi, Y., Pembuatan Papan Partikel Berbahan Baku Sabut Kelapa dengan Bahan Pengikat Alami (Lem Kopal), Jurnal Teknologi, 3(1), pp.22-32, 2010.

[13] Ekspor Pinang Sumut Meningkat Tajam, www.medanbisnisdaily.com (diakses pada 13 Juni 2019).

[14] Erwin, Erwin, Anjiu, Leo Dedy. Upaya Peningkatan Kualitas Sifat Mekanik Komposit Polyester dengan Serat Bundung (Scirpus Grossus). POSITRON, 6.2: 77-81.

[15] Suherti, Diba F, Nurhaida, Sifat Fisik dan Mekanik Papan Partikel dari Kulit Durian (Durio sp) dengan Konsentrasi Urea Formaldehid yang Berbeda. Jurnal Hutan Lestari, 3(1), pp 510-515, 2014.

[16] Rismayani S, Achamad S.T. Pembuatan BioBriket Dari Limbah Sabut Kelapa dan Bottom Ash. Arena Tekstil, 26 (1), pp 47-54, 2011.

[17] Tyas, S.I.S., Studi Netralisasi Limbah Serbuk Sabut Kelapa (Cocopeat) Sebagai Media Tanam, Fakultas Peternakan, IPB, Bogor, 2000.

[18] Erwan, Faryuni DI, Wahyuni D, Sintesis dan Analisis Sifat Fisik dan Mekanik Papan Komposit dari Limbah Pelepah Sawit dan Sabut Kelapa, Prisma Fisika, 3(3), pp 93-100, 2015.

[19] Food and Agriculture Organization. 1996. Plywood and Other Wood Based Panels. Food and Agriculture Organization of the United Nation. Rome.

[20] Nababan M. Pengaruh Suhu Kempa Terhadap Sifat Fisis dan Mekanis Papan Partikel Dengan Menggunakan Campuran Perekat Urea Formaldehida dan Isosianat. Universitas Sumatera Utara. Fakultas Kehutanan, 2017.

[21] Anton, Pembuatan dan Uji Karakteristik Papan Partikel dari Serat Buah Bintaro (Cerbera Manghas), Institut Pertanian Bogor, Fakultas Teknologi Pertanian, Bogor, 2012.

[22] Walter R, Swift EJ, Sheikh H, Ferracane JL. Effects of temperature on composite resin shrinkage. Quintessence International 2009, 40(10):843-47
[23] Yiu CKY et al. Effect of hidrophilicity and temperature on water sorption of dental adhesive resins. Biomaterials 2006;27:16951703.

[24] Haygreen, J.G. dan Bowyer, J.L., Hasil Hutan dan Ilmu Kayu, Sujipto, A.H, penerjemah; Yogyakarta: Gajah Mada University Press. Terjemahan dari : Forest Product and Wood Science, 1996.

[25] Bowyer, J.L., Shmulsky, and Haygreen, J.G., Forest Products and Wood Science - An Introduction, Fourth edition, Iowa State University Press, 2003.

[26] Darmanto, S., Sediono, W., Setyoko, B. dan Murni, Kajian Pelepah Kelapa Sebagai Serat Komposit (Study of Coconut Branch As Composite Fiber). Jurnal TEKNIK, 28(1), pp. 66-70, 2007.

[27] Olanda, S. dan Mahyudin, A., Pengarug Penambahan Serat Pinang (Areca Catechu L.Fiber) Terhadap Sifat Mekanik dan Sifat Fisik Bahan Campuran Semen Gipsum, Jurnal Fisika Unand, 2(2), pp. 94-100, 2013.

[28] Ruhendi, S.; Desy, N.K., Firda, A.S.; Hikma, Y., Nurhaida., Sahriyanti, S. dan Tito, S., Analisis Perekatan Kayu, Fakultas Kehutanan, Institut Pertanian Bogor, Bogor, 2007.

[29] Widarmana, S., Panil-panil Berasal dari Kayu sebagai Bahan Bangunan, Prosiding Seminar Persaki, Pengurus Pusat Persaki, pp. 79, 1997.

[30] Kahfi, F., Sifat Fisis Mekanik Papan Gipsum dari Tandan Kosong Kelapa Sawit (Elaeis guineensis Jacq) dengan Perlakuan Perendaman dan Variasi Kadar Gipsum, Depertemen Kehutanan, Universitas Sumatra Utara, Medan, 2007.

[31] Riki, Dirhamsyah, M. dan Setyawati, D., Sifat Fisik-Mekanik Papan Partikel dari Limbah Finir Berdasarkan Jumlah Lapisan dan Kerapatan, Jurnal Hutan Lestari, 6(4), pp. 720-732, 2018.

[32] Subiyanto, B. R., Saragih dan Husin, E., Pemanfaatan Serbuk Sabut Kelapa Sebagai Bahan Penyerap Air dan Oil Berupa Panen Papan Partikel, Jurnal Ilmu \& Teknologin Kayu Tropis, 1(1), pp. 26-34, 2003.

[33] Setiawan, B., Kualitas Papan Partikel Sekam Padi, Departemen Hasil Hutan, Fakultas Kehutanan, Institut Pertanian Bogor, Bogor, 2008. 
POSITRON Vol. 10, No. 1 (2020), Hal. 8 - 18

[34] Maulana, D., Dirhamsyah dan Setyawati, D., Karakteristik Papan Partikel dari Batang Pandan Mengkuang (Pandanus artocarpus Griff) Berdasarkan Ukuran Partikel dan Konsentrasi Urea Formaldehida, Jurnal Hutan Lestari, 3(2), pp. 247-258, 2015.
[35] Dynanty, S.D.P. dan Mahyudin, A., Pengaruh Panjang Serat Pinang Terhadap Sifat Mekanik dan Uji Biodegradasi Material Komposit Matriks Epoksi dengan Penambahan Pati Talas, Jurnal Fisika Unand, 7(3), pp. 233-239, 2018. 